\title{
GROUND HERBACEOUS FLORA IN UNLOGGED SITES OF SINHARAJA WORLD HERITAGE SITE
}

\author{
M M D J Senaratne and B M P Singhakumara \\ Department of Forestry and Environmental Science, \\ University of Sri Jayewardenepura, \\ Nugegoda.
}

The composition and distribution of herbaccous plants were investigated at Sinharaja World Herilige site.

Previously unlogged forest areas were selected for the present study. Several transects were marked purposively in each site from valley to ridge to study the topographical variation of herbaceous plant distribution. Circular plots, each $10 \mathrm{~m}^{2}$ were demareated on each transect 10 study the herbaceous floria. In addition. $200 \mathrm{~m}^{2}$ plots surrounding the $10 \mathrm{~m}^{2}$ plot were marked to enumerate the tree species in the area. The distance between two. $200 \mathrm{~m}^{2}$ plots was $20 \mathrm{~m}$.

In each plot number of plant species was recorded. Voucher specimens were prepared for identification of species found in plots ats well as outside the plots. Dominance diversity curves and Shannon diversily indices were prepared for each transect.

Ninely one species helonging to 40 families were recorded. Twenty nine of 91 species are found outside plots. The estimation of individuals of herbaceous plants per hectare was 21.790. Herbs and herbaceus climbers represented $38.47 \%$ of the total herbaceous flora. Fern and fern allies represented $45.67 \%$ and grasses and sedges $15.84 \%$. respectively.

Species rich families were Zingiberaceac (6 spp.) and Rubiaceac (5 spp.) Density dominance families were Rubiaceae $(6.97 \%)$ Zingiberaceae $(3.9 \%)$. Mysinaceac (3.6\%), Polipodiaceae $(17.3 \%)$. Dennestacdiaceac $(7.8 \%)$ Cyatheaceae $(3.8 \%)$ and Cyperaaceae $(5.5 \%)$. Diversity indices in valley and ridge were 0.2153 and 0.1754 , respeclively.

Results indicate the localised distribution of herbaceous species in understory vegetation of lowland rain forest. This may be due to the differences in micro habitats from valley to ridge.

Preceedings of the Fourth Annual Forestry and Enviromment Symposium 1998 of the Department of Forestry and Emironmental Science, University of Sri Jayewardenepara, Sri Lanka 